\title{
GEOLOGIGAL MAGAZINE
}

journals.cambridge.org/geo

Submit your paper online http://mc.manuscriptcentral.com/geo
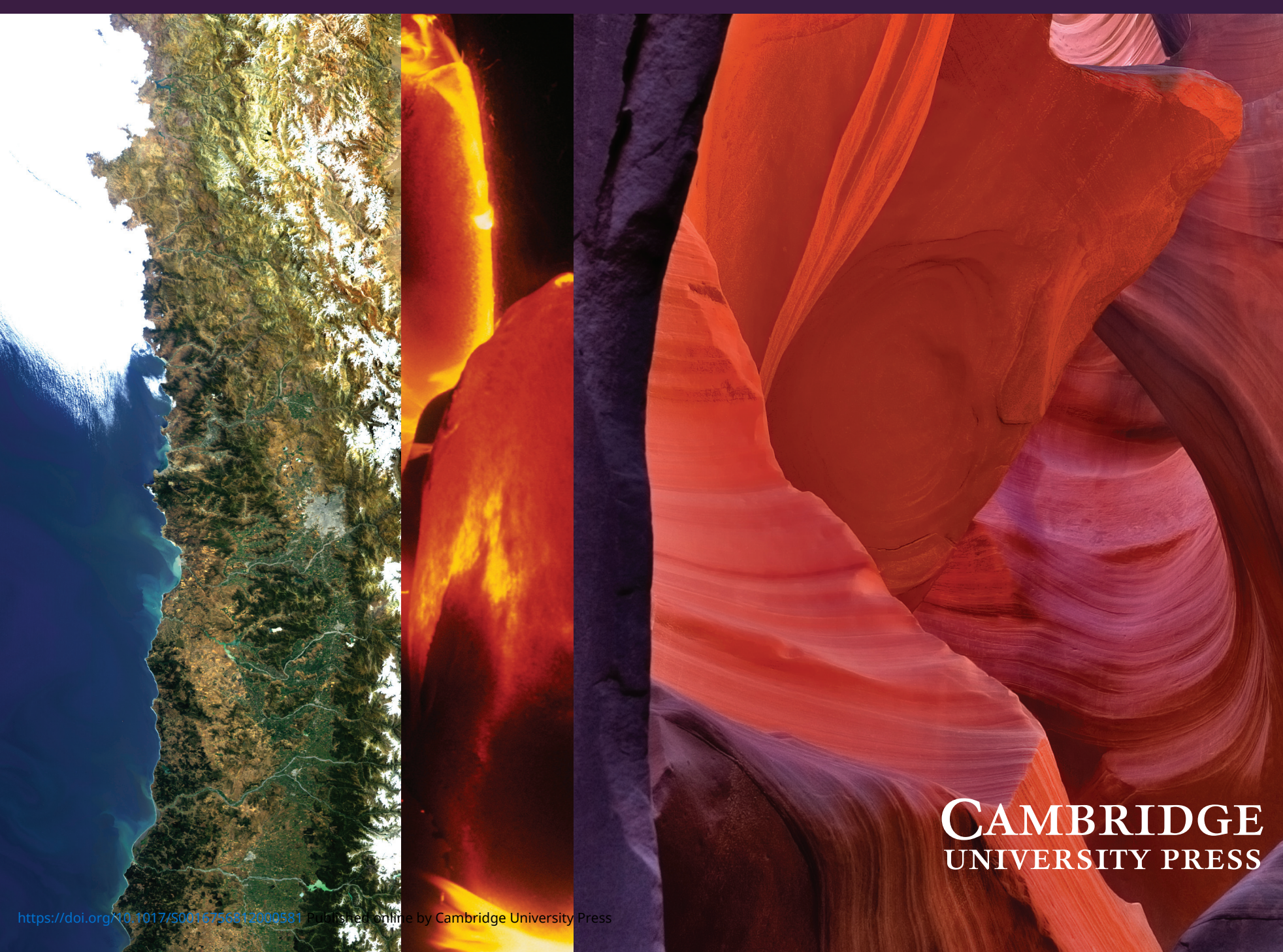


\section{Geological Magazine}

\author{
E DITORS \\ M. B. Allen, G. E. Budd, \\ P. T. Leat, A. G. Whitham
}

TECHNICAL EDITOR

BOOK REVIEW EDITOR

Dr S. Thomas

email:geolmag@cambridge.org
EDITORIAL BOARD

Dr P. M. Barrett, Department of Palaeontology, The Natural History Museum, Cromwell Road, London SW7 5BD, UK.

Professor R. L. Gibson, School of Geosciences, University of the Witwatersrand, Private Bag 3, 2050 Wits, Republic of South Africa.

Professor J. Grotzinger, Department of Geological \& Planetary Sciences, Caltech, 1200 E. California Blvd, Pasadena, CA 91125, USA.

Dr J. Imber, Department of Earth Sciences, University of Durham, Science Laboratories, South Road, Durham DH1 3LE, $U K$.

Dr H. C. Jenkyns, Department of Earth Sciences, University of Oxford, Parks Road, Oxford OX1 3PR, UK.
Professor D. I. M. Macdonald, Department of Geology \& Petroleum Geology, University of Aberdeen, Meston Building, King's College, Aberdeen AB24 3UE, UK.

Dr K. J. McNamara, Department of Earth Sciences, University of Cambridge, Downing Street, Cambridge CB2 3EQ, UK.

Professor R. J. Norris, Department of Geology, University of Otago, P.O. Box 56, Dunedin, New Zealand.

Professor M. P. Smith, Lapworth Museum of Geology, University of Birmingham, Edgbaston, Birmingham B15 2TT, UK.

Dr P. B. Wignall, Department of Earth Sciences, University of Leeds, Leeds LS2 9JT, UK.
The Geological Magazine was originally established in 1864 and has been published continuously ever since. It covers the whole field of earth sciences, has a worldwide readership and has a particular strength in providing a niche for interdisciplinary papers and papers that would be of interest to geologists from many different specialities. Papers of any length are considered, provided that the length is justifiable.

The Magazine publishes both original and review articles, rapid communications, discussions of papers which have already appeared in the Magazine, book reviews and a list of new publications.

There are no page charges for papers published in the Magazine.

(C) Cambridge University Press 2012

\section{Internet Access}

This journal is included in the Cambridge Journals Online service which can be found at http://journals.cambridge.org. For further information on other Press titles access http://www.cambridge.org. Geological Magazine (ISSN 0016-7568) is published in six parts in 2012, January, March, May, July, September and November. Six parts form a volume in 2012 .

The subscription price (excluding VAT) of volume 149, 2012, which includes print and electronic access, is $£ 605$ (US $\$ 1025$ in USA, Canada and Mexico). The electronic-only price available to institutional subscribers is $£ 500$ (US $\$ 910$ in USA, Canada and Mexico). Single parts are $£ 105$ net (US $\$ 190$ in USA, Canada and Mexico) plus postage. Students (who must get a statement signed by a tutor) may subscribe at the reduced rate of $£ 58$ (\$101). Prices include delivery by air where appropriate. Orders, which must be accompanied by payment should be sent to any bookseller or subscription agent, or direct to the publisher: Cambridge University Press, The Edinburgh Building, Shaftesbury Road, Cambridge CB2 8RU. Subscriptions in the USA, Canada and Mexico should be sent to Cambridge University Press, Journals Fulfillment Department, 100 Brook Hill Drive, West Nyack, New York 10994-2133.
EU subscribers (outside the UK) who are not registered for VAT should add VAT at their country's rate. VAT registered subscribers should provide their VAT registration number. Japanese prices for institutions are available from Kinokuniya Company Ltd, P.O. Box 55, Chitose, Tokyo 156, Japan. Periodicals postage paid at New York, NY, and at additional mailing offices. POSTMASTER: send address changes in USA, Canada and Mexico to Geological Magazine, Cambridge University Press, 32 Avenue of the Americas, New York, NY 10013-2473, USA.

Copying: This journal is registered with the Copyright Clearance Center, 222 Rosewood Drive, Danvers, Mass. 01923, USA. Organizations in the USA who are also registered with C.C.C. may therefore copy material (beyond the limits permitted by sections 107 and 108 of US copyright law) subject to payment to C.C.C. of the per-copy fee of $\$ 12.50$. This consent does not extend to multiple copying for promotional or commercial purposes. Code 0016-7568/2012 \$12.50.

Organizations authorized by the Copyright Licensing Agency may also copy material subject to the usual conditions.

For all other use, permission should be sought from Cambridge or the American Branch of Cambridge University Press.

Claims for missing issues can only be considered if made immediately after receipt of the subsequent issue.

Advertising: Details of advertising in Geological Magazine may be obtained from the publisher.

This journal issue has been printed on FSC-certified paper and cover board. FSC is an independent, non-governmental, not-for-profit organization established to promote the responsible management of the world's forests. Please see www.fsc.org for information. 